11. Фабіан М. Особливості семного складу етикетних слів української, англійської та угорської мов. Записки з романо-германської філології. 1999. Випуск 5. С.187-190.

12. Fabian M. Lexico-semantic Analysis of the Nouns Denoting Respect in English and Ukrainian. English versus Slavic. Lexicon in a Morphological and Semantic Perspective. 2017. Volume 5. P. 63-88.

13. Словник української мови : у 11-ти т. / [І. К. Білодід та ін.]. - К. : Наукова думка, 1970 - 1980. - Т. 1 - 11.

14. Oxford English Dictionary / Being a corrected re-issue with an introduction, supplement and bibliography of a new English dictionary on historical principles / Ed. by: J. A. H. Murray : Vol. 1-12. - Oxford : the Clarendon Press, 1970.

УДК 811.124'38+81-2: 808.51Лівій

DOI: $10.24144 / 2617-3921.2020 .18 .178-186$

Емілія Швед

кандидат філологічних наук, дочент, завідувачка кафедри класичної та румунської філології ДВНЗ «Ужсгородський наџіональний університет» orcid.org/0000-0002-9477-7579

м. Ужгород, Україна, тел.0956953050,emilija.shwed@uzhnu.edu.иа

Оксана Дацьо старший викладач кафедри класичної та румунської філології ДВНЗ «Ужсгородський національний університет» orcid.org/0000-0001-6974-9544 м. Ужгород, Україна, тел.0508229204, oksana.datio@uzhnи.еdu.иа

\title{
Лінгвістичні особливості промов історичних осіб твору Т. Лівія «Історія» (на матеріалі промов I-ї декади твору)
}

Анотація. Стаття присвячена вивченню власне лінгвістичної сторони стилю промов історичних осіб твору Т. Лівія «Історія». У колах науковиів існують суперечливі думки щодо специифіки мови автора «Історії». Одні дослідники схильні вважати, що мова промов тяжіє до класичної, інші ж зараховували Лівія до «срібної» епохи. Ми поставили за мету дослідити окремі аспекти мови та стилю промов першої декади «Історії», а саме їх власне лінгвістичну сторону, - лінгвістичні особливості промов. У науковій літературі відсутнє комплексне наукове вивчення цієї проблеми. 
Дослідження засвідчує, ще мова промов слугує теж вагомим фактором аргументації. $B$ результаті аналізу архаїзми промов поділились на матеріальні та стилістичні, причому, перші значно превалюють. Зустрічаємо у промовах елементи вульгарної латини, неотеризми, не засвідчені у класичній латинській мові. Імовірно, щзо автор, описуючи подї давнини, свідомо вводить поетизацію мови. Особливістю мови є часті синкоповані $і$ неасимільовані форми. В узусі автора «Історії» незначна кількість маловживаних та застарілих слів, тому мова його промов відповідає чотирьом основним вимогам Ціџерона: правильності, ясності, відповідності, пишності. Незважаючи на чистоту і правильність, мову промов через поетичність, часті відхилення від класичної норми, правильніше буде вважсати мовою перехідного періоду, що знаменує перехід до «срібної латини».

Ключові слова: риторика, стилістичні особливості, давній Рим, Тіт Лівій, його твір «Історія» (промови твору), лінгвістичні особливості промов.

Abstract. The article is devoted to the study of the linguistic side of speeches style of historical figures from T. Livy's «History». In research circles there exist contradictory thoughts concerning the language specificity of «History» author. Some tend to consider the language of speech to be classical, whereas the others include Livy in "silver" epoch. We have put the aim to study certain aspects of language and style of the first decade "History» speeches, namely their linguistic side - speeches' linguistic peculiarities. Complex research of this problem is absent in scientific literature.The study demonstrates that the language of speech is also a significant factor in argumentation. As a result of analysis performed, archaisms of speech are divided into material and stylistic ones, the former being much more prevalent. In the speeches, we find elements of vulgar Latin, neotericism, not peculiar to classical Latin. It is likely that the author, while describing the events of antiquity, deliberately introduces the poetisation of language. Frequent syncopated and non-assimilated forms become the peculiarity of the language used. There is a small number of underused and archaic words found in the vocabulary of the «History» author, so the language of his speeches meets the four basic requirements of Cicero: correctness, clarity, relevance, pomp. Despite its purity and correctness, the language of speech due to poetry, frequent diversion from the classical norm, is more correct to be considered the language of transition, which marks the transition to «silver Latin».

Keywords: rhetoric, stylistic features, ancient Rome, Titus Livy, his work «History» (speeches of the work), linguistic features of speeches.

Вступ. Протягом століть досягнення риторики практично освоювалось різними науками: поетикою, стилістикою, логікою. Оскільки головним питанням стилістики, як і риторики є питання ефективного використання мови, симбіоз риторики зі стилістикою є дуже тісним. Стилістика, фактично, 
бере початок у риториці, джерела стилістики і сучасної лінгвостилістики слід шукати в класичній риториці.

Перебуваючи в стані зародку у працях I.О. Бодуена де Куртене, О.О. Потебні, лінгвостилістика оформилась як наука у працях Л.В. Щерби, Б.А. Ларіна, В.В. Виноградова, Г.О. Винокура. Саме у 20-і роки формується методологія вивчення художньої мови як ідейно-естетичної єдності. На даний час, в умовах глибокого вивчення основ ораторського мистецтва, спроб поєднання традиційних риторичних правил і прийомів з філософськими та лінгвістичними категоріями нового часу, появою у зв'язку з цим нових ідей та гіпотез, добрим підгрунтям стає детальне фактологічне вивчення відповідного текстового матеріалу античної епохи.

Цінним матеріалом у цьому плані $є$ твір відомого римського історіографа Тіта Лівія «Ab urbe condita», чи скорочено в українському перекладі «Історія», що наповнений численними промовами історичних осіб, які укладені автором 3 великою риторичною майстерністю.

У працях вітчизняних та зарубіжних дослідників неодноразово висловлювалася думка про те, що промови історичних осіб, які автор вводить у свій твір є втіленням усіх кращих традицій античної риторики $[1 ; 2 ; 3]$. Саме у цих промовах проявив себе ораторський талант автора. Вони стали синтезом всього цінного, нагромадженого грецькою та римською риторичною наукою долівієвого періоду.

Дослідженню специфіки промов, що ввійшли у «Історію» Лівія, присвячено цілий ряд робіт. Це праці I. Тена, Г. Бернгарді, С. Стацея, I. Брунса $[9 ; 11 ; 17 ; 12]$.

Знайомлячись 3 більшістю праць, присвячених цій темі, звертаємо увагу на той факт, що у них детальному вивченню піддаються в основному промови інших декад «Історії», промови ж першої залишаються поза увагою дослідників. Виходячи з цих міркувань ми поставили за мету дослідити окремі аспекти мови та стилю промов першої декади «Історії», а саме їх власне лінгвістичну сторону, - лінгвістичні особливості промов. У науковій літературі відсутнє комплексне наукове вивчення цієї проблеми.

У колах науковців існують суперечливі думки щодо специфіки мови автора «Історії»: одні дослідники схильні вважати, що мова промов тяжіє до класичної, інші ж зараховували Лівія до «срібної» епохи.

Завданням нашого дослідження $є$ фіксація та аналіз специфіки мови автора «Історії» та виведення своєї точки зору щодо специфіки лінгвістичних особливостей промов, які, без сумніву, служать у промовах теж важливим засобом аргументації.

Методологія та методи дослідження. Матеріалом дослідження слугують промови історичних осіб першої декади твору Т. Лівія «Ab urbe condita», що у сумі складають 914 Вайсенборнівських рядків [19; 20]. Під час дослідження застосовувався описовий метод, що базувався на наступних прийомах: класифікації та систематики, культурно-історичної інтерпретації, а також 
використовувалася компонентна та контекстна методика лінгвістичного аналізу.

Виклад основного матеріалу дослідження. Досліджуючи найважливіші засоби аргументації у структурі промов, неможливо оминути і власне лінгвістичну сторону стилю Тіта Лівія, - особливості мови історика.

Ще Квінтіліан у трактаті «Про виховання оратора» зазначав, що «у мови звичайної якась одна суть, а у мови досконалого оратора друга» $(12, \S 10,40$ 43). Автор «Історії» - палкий патріот, якому притаманна своя манера поєднання та добору значущих одиниць. Саме дослідивши принципи авторського підбору лексики, отримуємо можливість осмислити розуміння його стилю, - важливим об'єктом дослідження стає власне лінгвістична сторона стилю Лівія. Автор ставиться до ораторського мистецтва як до художньої творчості.

У промовах першої декади зустрічаємо чимало архаїзмів. Це пояснюється як впливом джерел, - «архаїзми, що йдуть від анналістів» [6, с. 181], так і бажанням надати мовного колориту, характерного для зображуваної епохи. Весь склад пасивного словникового складу- архаїзми в процесі дослідження розподілився на дві групи: 1) архаїзми матеріальні, тобто слова, що означають предмети і поняття, які вийшли із ужитку та належать до старовини; 2) архаїзми стилістичні, тобто слова - синоніми до можливих паралельно інших слів, що не мають забарвлення старовини. Перша група складає найчисельніший клас архаїзмів промов, їх ще називають історизмами. Вживання їх зумовлено прагненням автора відтворити культурно-побутовий колорит епохи, вони служать засобом передавання певних історичних реалій. Принагідно зауважимо, що матеріальні архаїзми визначаємо стосовно епохи автора. Серед історизмів, які у вжитку історіографа, слова, що характеризують класову структуру суспільства, соціальний стан, суспільні взаємини, назви урядових та релігійних чинів, назви старовинної зброї: tribunus /III, 17, 2/, народний трибун; plebs /III, 17, 5/, - плебеї; virgas et secures /III, 45, 7/, - пучки прутів і сокири; decemvir /III, 67, 7/, - децемвір; scita plebis /III, 67, 9/, - рішення зборів плебеїв; plebicola /III, 67, 10/, - захисник плебсу; rex/IV, 3, 9/, цар; pontifex /IV, 4, 2/, - понтифік; comitia curiata /V, 52, 6/, - збори курії; comitia centuriata /V , 52, 6/, - збори центурії; interrex /IX, 34, 12/, - міжцар; dictatura /IX, 34, 12/, - диктатура. Для детальнішого відтворення колориту епохи Т. Лівій вводить у промови численні імена історичних діячів минулого: Appius Herdonius /III, 17, 2/, - Аппій Гердоній; Romulus /III, 17, 6/, Ромул; Appius Claudius /III, 45, 6/, - Аппій Клавдій; Canuleius /IV, 3, 1/, Канулей; Numa Pompilius /IV, 3, 11/, - Нума Помпілій; Servius Tullius /IV, 3, 12/, Сервій Туллій; Titus Tacitus Sabinus /IV, 3, 12/, - Тіт Таціт Сабін; Marcus Manlius /VI, 15, 5/, - Марк Манлій; Aulus Cornelius /VI, 15, 9/, - Авл Корнелій; Cassius /VI, 18, 9/, - Касcій; Lucius Sextius /VI, 40, 1/, - Луцій Секстій; Gaius Licinius /VI, 40, 7/, - Гай Ліціній; Camillus /VI, 40, 17/, - Каміл; Lucius Papirius Cursor /IX, 34, 12/, - Луцій Папірій Курсор; Gaius Licinius Stolo /X, 8, 2/, - Гай Ліціній Столон і чимало інших. 
Головна функція історизмів чисто номінативна, часом вони надають промовам урочистого колориту, а прізвище Tarquinius /IV , 3, 11/, - Тарквіній - вживається як символ зла та тиранії.

Стилістичні архаїзми зустрічаємо у промовах відносно рідко. Так, T. I. Кузнєцова зазначає, що архаїзм tempestas, який Лівій вживає замість tempus /X,11, 9/, автор, очевидно, запозичив від анналістів [6, с. 181]. Цікаво, що в першій книзі Лівій вживає форму duellum замість bellum /I, 32, 12/. У промовах поряд з іменником класичної латинської мови $p l e b s,-i s$ автор вживає архаїчну форму plebes, -ei /VI, 18, 14/ і паралельно форми plebeius, -i /IV, 3, 7/. Також зустрічаємо використання форми дієслова faxo, що є характерна для архаїчної латини. Відомо, що таку форму часто вживав Енній, можливо, саме впливом джерела зумовлене іiі застосування автором «Історії». Ці архаїзми вжиті Лівієм із стилістичною метою. Дослідження показало, що Лівій намагається уникнути «застарілих слів» та «неясності мови» [5, с. 488].

У текстах промов історичних осіб трапляються і поодинокі елементи вульгарної латини: consortium /IV, 5, 5/, - співтовариство в той час, як у класичній латинській мові consortio; introducti ... ad senatum /III, 4, 6/, - введені в сенат, а в Ціцерона: introducti in senatum; Лівій вживає форму postmodum /I, 9, 15/, - потім, а згодом у другій книзі - postmodo /I, 27, 5/. Для мови Лівія характерні так звані verba frequentativa (частотні слова), зокрема у I декаді автор вживає форму dictitare, стверджувати 15 раз; а в III декаді - 3 рази, rogitare, розпитувати у I декаді 18 раз, а в III декаді - 2 [15, с. 848]. Відомо, що літературний противник Лівія із аттикістичного табору Азіній Поліон знаходив у мові «Історії» елементи провінціоналізму - verba peregrina. Ці слова, як припускають, характерні для місцевості, де жив Лівій, тому таке явище у мові Лівія отримало назву «patavinitas». Слідів цього патавізму вчені шукали здавна, проте даремно, адже історію одного слова прослідкувати дуже складно, воно випадково могло не вживатися у тих текстах, що дійшли до нас [5, с. 488]. Зокрема, В. Еккерт подає у своїй праці вичерпний перелік літератури, присвяченої дослідженню патавізму у Лівія [13]. Ми можемо лише припустити, що автор все ж вживає деякі провінційні слова чи звороти, характерні для його рідного міста Падуї. Однак не слід забувати яка надмірна прискіпливість характерна для Азінія Поліона. У наш час сліди patavinitas виявити практично неможливо.

Для мови I декади властива поетичність. Великий вплив на Лівія у цьому плані мали «Аннали» Еннія, що, як відомо, відзначаються своєю поетичною забарвленістю. Лівій, дотримуючись настанов Ціцерона, прагне висловлюватись виразно, чітко, виблискуючи яскравими словами та образами, вводячи навіть у прозу віршовий розмір [10, с. 215]. Саме це його спонукає до введення численних поетичних елементів у мову. На цю рису мови автора «Історії» вказує такий дослідник твору, як В.І. Модестов [8, с. 178]. T.I. Кузнєцова зауважує: «Про вплив Еннія може свідчити напівпоетична манера вираження думок в перших книгах Лівія, де проза інколи наближається 
до ритму дактилічного гекзаметра [6, с. 111]. Наведемо лише декілька зразків поетизації: сиріdo /I, 23, 7/, - пристрасть замість cupiditas; legiones /III, 19, 12/, - легіони у значенні «війська». Чи до прикладу: Vos etiamsi tunc faciendum non fuerit, nunc ubique faciendum putatis; ego contra - nec id mirati sitis... /V, 53, 3/, - Ви, хоча тоді не треба було робити, тепер, вважаєте, слід зробити, я ж дотримуюсь протилежної думки - i не дивуйтеся цьому... Дослідник та коментатор твору Лівія вчений В. Вайсенборн зауважує, що вживання форми на зразок «пес» більш властиве поетам [19, с. 395]. Німецький вчений Тойфель неодноразово підкреслює вплив Вергілія та Еннія на стиль Лівія [18, с. 131]. Можливо, що в описі давніх подій автор свідомо поетизує мову. Вплив поетичної мови проявився у вживанні прикметників і дієприкметників замість іменників, прислівників - замість прикметників. Лівій, як і Ціцерон, залишається у поезії послідовником Еннія. Саме у поетичності мови проявилася наступаюча «срібна епоха» у розвитку латинської мови. Однак, більш за все поетичний колорит мови виявився у вживанні численних фігур і тропів, що послужить матеріалом подальших досліджень.

Промови багаті численними словами незасвідченими у класичній латинській мові, для них властиве особливе варіативне вживання окремих форм, як от: consentientia /II, 32, 9/, - згода, вживається слово поха, хоча правильніше вжити похіа у значенні «провина» [19, с. 140]. Цікавим є те, що у розповіді про найдавніші часи Лівій вводить слово stipendium, хоча воно виникло значно пізніше [19, с. 143]. Зустрічаємо і варіативне вживання форм finitumus /IV, 3, 4/, - сусідній і finitimus /V, 6, 7/; plerique /IV, 4, 7/, - в більшості, тоді як у класичній латині plerumque; ecnubere /IV, 4, 7/, - виходити заміж, а у класичній мові - enubere. Форма inmisceatur /IV, 4, 6/, - змішається вперше вжита Т. Лівієм для позначення кровного змішання, спорідненості; паралельно вживаються форми aecus /N, 3, 8/, - однаковий і aequus /V, 4, 2/. Маємо можливість спостерігати явище гіперкоректності: vicensimus /V, 4, 12/, двадцятий та vicesimus /IX, 34, 13/; паралельно вживаються частки: -lubetqualubet /V, 6, 12/, - який-небудь та -libet-quilibet/VI, 40, 6/; форма vinclum /VI, 15, 6/, - ланцюги та vinculum /VI, 18, 9/. Часто на початку питальних речень автор вживає слово hocine /VI, 40, 12/, яке не засвідчене у класичній мові. Такого роду неотеризми часом вживаються у досліджуваних промовах, як наприклад: occecinere /VI, 41, 8/, - співати, тоді як у класичній мові - occinere; характерне часте вживання форми cum quibus замість quibuscum, паралельних форм dextera i dextra, anteaquam i antequam.

Дослідник мови Лівія Л. Кюнаст зробив дуже цінну і важливу справу, у кінці своєї праці автор виділив так звані «seltene Wörter» у Лівія, - наведемо декілька прикладів, які він виділяє із першої декади: assuetudo /X, 1, 7/; confieret замість conficeretur /V, 50, 7/; devastare /IV, 59, 2/; fenebris /VI, 21, 5/ [14, c. 385388]. Для мови Т. Лівія характерне вживання синкопованих форм: scissem /III, 67, 2/, - знав би; vitassem /III, 67, 2/, - уникнув би; desiderastis /III, 67, 7/, побажали; creastis /III, 67, 9/, - вибрали; audieritis /V, 53, 3/, - вислухайте; 
aedicarunt /V , 53, 9/, - спорудили; succlamassent /VI, 40, 12/, - закричали б; abdicarunt /IX, 34, 21/, - відмовились від посади.

Із форм перфекта третьої особи множини вживаються форми на -ёre i érunt: contempsere /III, 67, 3/, - зневажити; novere /III, 67, 5/, - пізнати; tulerunt /VI, 4, 5/, - принесли; noluerunt /V, 4, 1/, - не знали; fuere /V, 4, 14/, - були. Часом в одному і тому ж реченні зустрічаємо паралельне використання і тої і іншої форм /V, 5, 5/. Частіше все ж в узусі автора форма на -ёrunt.

Специфікою мови Лівія $є$ часте вживання неасимільованих форм: inminere /III, 67, 2/, - погрожувати; adsueta /V, 54, 3/, - звична; adferre /IV, 4, 8/, приносити; inpediet /IV, 5, 6/, - перешкоджає; inpugnare /IV, 5, 7/, - нападати; inponere /V , 4, 10/, - накладати; inmortalibus /X, 7, 4/, - безсмертним; conparastis /IX, 34, 3/, - приготували. Неасимільовані форми у промовах домінують над асимільованими, останніх налічуємо порівняно мало.

Що стосується введення у промови vocabula peregrina sive externa (слів іншомовного походження), то в цьому плані автор дуже стриманий, - у промовах трапляються лише поодинокі слова такого типу, thensaurus /VI, 18, 9/, - скарб; barbarus /VI, 18, 9/, - ворог; pontifex /VI, 41, 9/, - понтифік.

Таким чином, приходимо до висновку, що Т. Лівій приділяє чималу увагу словесному вираженню мови. Його мова відповідає чотирьом основним вимогам Ціцерона щодо мови: правильності, ясності, відповідності, пишності. Автор дуже рідко послуговується маловживаними, застарілими словами. Мова ораторів ясна, легко сприймається, автор добре усвідомлює значення впливу ясності мови на ясність думки та їх взаємозв'язку у ораторському мистецтві. Лівій «вводить лише слова, які у всіх у вжитку і належать його часу» [9, с. 347]. Вміло підібрані слова автор укладає у свій улюблений зворот мови період. Не можна сказати, що маємо у промовах недостатньо коротких фраз, однак Лівій вважає, що найкраща форма мови для аргументацій - період. Плавну течію його великих періодів Квінтіліан назвав „lactea ubertas”. Філософ Сенека зараховував Лівія до числа найкрасномовніших, мовою історика захоплювались його сучасники, вона стала предметом наслідування для пізніших авторів, зокрема, Квінта Курція.

Постає питання, чи маємо ми право вважати мову промов класичною? Щодо цього у науковій літературі поширені досить суперечливі думки. Так, B.I. Модестов вважає, що поетичний вплив надав мові Лівія характер «срібного віку» [8, с. 282], подібної думки дотримується і Ф. Зелінський [7, с. 17]. Ряд німецьких дослідників дотримуються зовсім протилежної думки, зокрема, М. Шанц дає таку характеристику мови твору: «Його латинська мова може йти у порівняння 3 найкращими зразками класичних часів, лише, подекуди виступаючий у першій декаді поетичний колорит, нагадує про переломність епохи у історії мови» [16, с. 435]. Інші ж дослідники виправдовують автора, пояснюючи введення поетичних елементів свідомим прагненням надати опису давніх часів поетичного колориту та зазначають тяжіння автора «Історії» до класицизму [15, с. $849 ; 18$, с. 131]. Що ж до нашої точки зору, то 
виходячи із результатів дослідження мови промов першої декади, можемо зробити наступні висновки: незважаючи на те, що мова Лівія чиста і правильна, все ж вона має окремі особливості, що відрізняє ії від класичної норми. Тому правильніше буде вважати автора представником перехідної епохи між «золотим» та «срібним» періодами римської літератури.

Висновки 3 дослідження. Отже, дослідження власне лінгвістичної сторони стилю промов засвідчує, що їх мова теж служить вагомим фактором аргументації. Архаїзми промов поділились на такі дві групи: матеріальні та стилістичні. Якщо другі кількісно обмежені, то перших - велика кількість. Зустрічаємо у промовах окремі елементи вульгарної латини, неотеризми, не засвідчені у класичній латинській мові. Імовірно, що при описі подій давнини автор свідомо застосовує поетизацію мови. Лівій майже не використовує маловживаних і застарілих слів, тому мова його промов відповідає чотирьом основним вимогам Ціцерона: правильності, ясності, відповідності, пишності.

Таким чином, незважаючи на чистоту і правильність, мову промов через поетичність, часті відхилення від класичної норми, правильніше буде вважати мовою перехідного періоду, що знаменує перехід до «срібної латини».

Результати дослідження послужать дороговказом для подальшого вивчення промов, вивченню специфіки застосування автором фігур і тропів як засобів експресії та аргументації, що допоможе детальніше дослідити його ідіостиль.

\section{ЛIТЕРАТУРА}

1. Аннушкин В.И. Зачем нужна риторика? // Рус. речь. - 1988. - № 5. - C. 81-86.

2. Аннушкин В.И. Первая русская «Риторика». (Из истории риторической мысли). - Москва, 1989. - 63 с.

3. Античные риторики / Под ред. А.А. Тахо-Годи. - Москва, 1978. - 352 с.

4. Античные теории язика и стиля. - М.-Л., 1936. - 341 с.

5. История Римской литературы / Под ред. С.И. Соболевского. - Т. І. Москва, 1959. - 534 с.

6. Кузнецова Т.И., Миллер Т.А. Античная эпическая историография: Геродот. Тит Ливий. - Москва, 1984. - 210 с.

7. Ливий Тит. Нашествие Аннибала. Кн. 21 / Пер. с лат. и объясн. Ф. Зелинского. - Санкт-Петербург, 1914. - 164 с.

8. Модестов В.И. Лекции по истории римской литературы. Век Августа. - Киев, 1875. - 319 с.

9. Тэн И. Тит Ливий. Критическое исследование. - Москва, 1900. -398 с.

10. Цицерон М. Т. Три трактата об ораторском искусстве / Пер. с лат.: Под ред. М.Л. Гаспарова. - Москва, 1972. - 471 с.

11. Bernhardy G. Grundriss der Rommischen Literatur. - Halle., 1850. - S. 542545. 
12. Bruns J. Die Persŏhnlichkeit in der Geschichtsschreibung der Alten. - Kiel., 1897. $-84 \mathrm{~s}$.

13. Eckert W. De figurarum in Titi Livi ab urbe condita libris usu. - Diss. Vratislaviae, 1911. - 103 p.

14. Kühnast L. Die Hauptpunkte der Livianischen Syntax. - Berlin, 1871. $402 \mathrm{~s}$.

15. Paulys-Wissowa. Real-Encyclopädie der classischen Altertumswissenschaft. Stuttgart, 1926. - Bd. 25. - S. 816-852.

16. Schanz M. Geschichte der Römischen Literatur. - München,1914. - 573 s.

17. Stacey S.G. Die Entwicklung des livianischen Stiles. - Leipzig, 1896. - $661 \mathrm{~s}$.

18. Teufel W.S. Geschichte der Römischen Literatur. - Leipzig-Berlin. - Bd. II. 1910. - $349 \mathrm{~s}$

19. Titi Livi. Ab urbe condita libri / W. Weissenborn. - M. Müller.lib. I-VI. Lipsiae., 1910. - $396 \mathrm{~s}$.

20. Titi Livi. Ab urbe condita libri / W. Weissenborn. - Bd. III. Buch. VI-X.Berlin, 1876. $-220 \mathrm{~s}$.

УДК 007(410)+791.233:613.885+316.346.2-055.1

DOI: $10.24144 / 2617-3921.2020 .18 .186-197$

Filip Šera

Magister, Department of British and American Studies

Pavol Jozef Šafárik University in Košice orcid.org/0000-0001-7465-5825

Košice, Slovakia, 00421911218475

filip.sera@student.upjs.sk

\section{Gender in British media: homosexuality and masculinity in selected TV series}

Анотаиія. Взаємодія між маскулінністю та гомосексуальністю представляс особливий інтерес в рамках розгляду структури тендерних владних відносин Коннелла. В ній геї, вважається, перебувають в підлеглому становищі у гетеросексуалів, таким чином асоціюючи їх з фемінністю (жіночністю). Для боротьби з атрибутами фемінності геї впроваджують широкий спектр стратегій, орієнтованих на гіпермаскулінність та прихильність до вищих сочіальних класів, які обіцяють владу. Роль засобів масової інформації є ключовою у формуванні иієї образності. Метою изієі розвідки є проаналізувати два британські телесеріали, що зображують персонажів-геїв, щоб розкрити своєрідні особливості, які можуть вплинути 